\title{
An innovation platform for institutional change in Ghana's cocoa sector
}

\author{
Richard Adu-Acheampong ${ }^{1, *}$, Janice Jiggins ${ }^{2}$, Ebenezer Tei Quartey ${ }^{3}$, Nana Maxwell Karikari ${ }^{4}$, \\ William Jonfia-Essien ${ }^{4}$, Edward Quarshie ${ }^{5}$, Paul Osei-Fosu ${ }^{6}$, Maxwell Amuzu ${ }^{7}$, Charles Afari-Mintah ${ }^{8}$, \\ Kwasi Ofori-Frimpong ${ }^{3}$, Michael Owusu-Manu ${ }^{10}$, Nana Nyarko Eku X ${ }^{7}$, Owuraku Sakyi-Dawson ${ }^{9}$, \\ William Quarmine ${ }^{9}$ and Francis Otu Acquah ${ }^{11}$ \\ ${ }^{1}$ Cocoa Research Institute of Ghana, PO Box 8, Tafo-Akim, Ghana \\ 2 Wageningen University, PO Box 8130 EW, Wageningen, The Netherlands \\ ${ }^{3}$ Ghana Cocoa Board, Department of Research, PO Box 933, Accra, Ghana \\ ${ }^{4}$ Quality Control Company Limited, PO Box M54, Accra, Ghana \\ ${ }^{5}$ Cargill Ghana, Free Zones Area, Tema, Ghana \\ ${ }^{6}$ Ghana Standards Authority, PO Box MB 245, Accra, Ghana \\ 7 Cocoa Input Company, Accra, Ghana \\ ${ }^{8}$ Kuapa Kokoo, Kumasi, Ghana \\ 9 Department of Agricultural Extension, College of Agriculture and Consumer Sciences, PO Box 68, University of Ghana, Legon, Ghana \\ ${ }^{10}$ Ministry of Finance and Economic Planning, PO Box M40, Accra, Ghana \\ 11 Cocoa Organic Farmers Association, Akwadum (Brong Densuso), Eastern Region, Ghana
}

\begin{abstract}
Cocoa is a major source of employment, smallholder farmers' incomes, and export revenue in Ghana. However, by 2010 institutional constraints throughout the value chain were failing to sustain bean quality and cocoa production. A national-level innovation platform, comprising key public and private actors in the cocoa sector, was established in 2010 to analyse and act to address this concern. The members' initial inquiries revealed that: farmers indirectly were paying for the national mass spraying and Hi-Tech input programmes, both provided free at the point of delivery. As the largest components in the cost structure, these programmes to a large extent accounted for the low price paid to farmers for their beans; a volatile exchange rate regime meant that often the prevailing rate was not equal to its equilibrium level; policies that heavily taxed cocoa were destroying farmers' expectation of long-term profitability. This paper draws on data recorded from the beginning 2009 to end 2013 by means of theory-guided process tracing (TGPT), to show how the platform contributed to increased prices for farmers, to subsequent reform of the input supply arrangements, and to changes to the mass spraying programme. The key causal mechanisms identified are policy learning and progressive amendment of existing institutions. The paper concludes by drawing lessons for the role of an innovation platform.
\end{abstract}

Keywords: cocoa / price formation / value chain / pest control / stakeholder-led change

Résumé - Une plate-forme d'innovation pour le changement institutionnel dans la filière cacao au Ghana. Au Ghana, le cacao est une source importante d'emplois, de revenus pour les petits agriculteurs et de recettes d'exportation. Cependant, en 2010, il a été diagnostiqué que des contraintes tout au long de la filière avaient un impact négatif sur la qualité et la production de fèves de cacao. Une plate-forme d'innovation nationale, comprenant les principaux acteurs publics et privés de la filière cacao, a donc été mise en place en 2010 pour analyser le problème et y répondre. Les enquêtes initiales ont révélé : que les agriculteurs payaient indirectement pour les programmes nationaux de «pulvérisation de pesticides » et d'intrants « Hi-Tech », tous deux soi-disant disponibles gratuitement ; or, en tant que composantes les plus importantes dans la structure des coûts, ces programmes étaient en fait largement responsables du faible prix payé aux

\footnotetext{
* Corresponding author: $r$.aduacheampong@yahoo.co.uk
} 
agriculteurs pour leurs fèves ; qu'un régime de taux de change très fluctuant faisait que le taux en vigueur était rarement à son point d'équilibre ; que les politiques agricoles taxant lourdement le cacao réduisaient les espérances de rentabilité à long terme des agriculteurs. Le présent article utilise des données recueillies de début 2009 à fin 2013 pour montrer comment la plate-forme d'innovation a pu contribuer à une augmentation des prix payés aux agriculteurs, à la modification des contrats d'approvisionnement en intrants et à la réforme du programme de pulvérisation de pesticides. Les principaux mécanismes explicatifs identifiés sont l'apprentissage politique et l'évolution progressive des institutions en place. L'article en tire des conclusions sur le rôle possible d'une plate-forme d'innovation.

Mots clés : cacao / prix / filière / pesticides / innovation / acteurs

\section{Introduction}

This paper addresses the contribution of an innovation platform (IP) to bringing about significant institutional change in Ghana's cocoa industry. The research on which this paper is based was carried out as part of the Convergence of SciencesStrengthening Innovation Systems programme (COS-SIS). The concept of IPs adopted by COS-SIS recognised three things: that purposeful change is about more than technology; that if innovations are to persist they need to be enabled by appropriate institutional conditions; and that these characteristics in turn entailed effort to embed the changes shown to benefit smallholders in agricultural policy, administration and management at national, district and local levels. The initial working definition thus was 'a multi-stakeholder group of committed individuals seeking purposeful socio-technical and institutional change at a range of levels through diagnostic studies, experimentation and strategic actions to bring joint learning into use' (Hounkonnou et al., 2016). COS-SIS built on the findings of an earlier programme that the technology development outcomes of local collaboration among farmers, extension workers and researchers were not sufficient to drive change in the institutional conditions that discouraged the farmers from continuing to use the proven technologies (Sterk et al., 2013). COS-SIS thus set out to explore how purposeful effort led by IPs in each of nine agro-industry domains in Mali, Ghana and Benin might open opportunity for innovation in the institutional conditions confronting smallholders. The programme's and this paper's overall research questions were: could the IPs bring about significant socio-technical and institutional changes? If so, how, and with what effects on the institutional regime governing each industry?

The programme sought more than simply 'change over time'. Innovation was understood to mean purposeful transformation in prevailing institutional conditions so as to enable 'different things to be done', and for the actors concerned 'to do them differently'. Following Faletti and Lynch (2009) such effort was considered throughout in terms of complex interactions and multi-level relationships that coevolve with their context. The concept of institutions was understood broadly, to encompass formal and informal rules and regulations, norms and routine practices and behaviours.

Cocoa is the most important agricultural commodity in Ghana, and is based on smallholder production. In 2009, it involved some 800,000 smallholders with farm sizes ranging from 0.4 to 4.0 ha (Baah and Garforth, 2008). The sector is governed under the authority of the Ghana Cocoa Board (COCOBOD), supported and regulated by the Ministry of Finance and Economic Planning and a Board of Directors. At the start of this research in 2009 , it contributed $84.9 \%$
(US\$ 1.865 billion) of the total US\$ 2.197 billion foreign exchange earnings of the agricultural sector. Production had increased from 395,000 metric tons in 2000 to more than one million metric tons in 2010-2011 seasons. The cocoa sector development strategy in 1999 set a target of increasing productivity and output to $1,000,000$ metric tons by 2010 ; by 2011 , output exceeded the target. However, industry leaders noted with concern the deteriorating quality of the beans delivered by the farmers and the rapid aging of the cocoa farming population.

The cocoa domain, for reasons of its economic importance and industry concerns about sustaining market share and the quality price premium, was selected by a national-level expert committee convened by COS-SIS, for inclusion in the Ghana programme (Hounkonnou et al., 2016; Adjei-Nsiah et al., 2013). The IP subsequently was established by leading industry actors at the national level (see further, Sect. 2), who were motivated by their desire to tackle the deteriorating conditions in the cocoa industry (Nederlof and Pyburn, 2012). They were particularly concerned that young farmers were not joining the industry and that cocoa bean quality was declining; they attributed both trends to the poor price paid to farmers, and to the prevailing institutional arrangements for pest management and input supply (Adu-Acheampong et al., 2014). The initial problem the IP's members sought to address was the cocoa price regime. Each member was identified and invited to join the IP as an interested individual and not as a formal representative of a sector or organisation. On the basis of prior experience this was thought necessary to avoid the often-sterile debates of official meetings that gave rise to expressions of defensive self-interest and power plays. However, each individual was sufficiently senior to make commitments and decisions on behalf of their organisation on the basis of the group's joint learning about what would benefit the industry as a whole.

This article presents and analyses the Cocoa IP's experience. It first tracks the members' initial effort to explore inter-related aspects of the price policy regime that prevailed in 2009, arising from the discovery at their first meeting that none of the IP members actually understood what information was taken into account establishing the key industry price indicator, the free-on-board (f.o.b) price of exported beans, or which cost components were considered in the annual determination of the price paid to producers. It is shown how the outcomes of their initial efforts led on to further cycles of policy learning and progressive amendment of a range of other institutions.

First the methodology and the key features of the context are presented. The findings and analysis are reported in two ways: first as a process narrative, secondly by identifying and analysing the causal mechanisms that led to the series of institutional innovations. The paper concludes by discussing some generic lessons. 


\section{Methodology}

The COS-SIS research methodology was based on the following initial process: a diagnostic study of the institutional constraints and opportunities in the industry (Quarmine et al., 2014); stakeholder analysis to identify initial members of the IP; and preliminary analyses by the IP members to identify what would need to be changed, how such changes might be brought about, and by whom. These analyses included probing the contextual space for change, the incentives any actor (individual and organisational) might have to make changes, and who might act as a 'champion' of the desired changes (van Paassen et al., 2014).

Thereafter, across the entire programme, a standard set of data was recorded more or less in real time by a part-time research associate (RA) attached to each IP (Jiggins et al., 2016). The RAs also facilitated the work of the IPs. The data, analyses and competing interpretations were reviewed and analysed at COS-SIS' annual regional and international symposia, and approximately three times a year at workshops organised in West Africa up to the end of 2013, attended by the RAs, national coordinators and the five members of the RA Support Team (composed of researchers from The Netherlands, Ghana and Benin). In addition, as their understanding and capacities developed, the IP undertook or commissioned a series of investigations and institutional experiments to test and enact the desired changes.

The standard data sets, and related observation and documentation protocols, concerned principally the processes and mechanisms of change, and the co-evolving relationships embedded in the institutional elements identified in Avelino and Rotmans (2009), and Fuchs and Graab (2011). In the cocoa case, the IP identified as 'problematic' the following elements: official and informal rules, including policy frameworks (legitimising action and decisions); practices and incentives (constituting the material structures for action); the scope and quality of relationships; and the rules for interpreting meaning and knowledge development (creating fresh understanding of what is significant and who and what is involved in sensemaking). They provided detailed evidences to reveal how and why each of these elements was constraining the industry's performance and/or blocking desired change, and then used this information to build their work programme.

Theory-guided process tracing (TGPT) protocols require the adoption of explicit hypotheses against which to periodically review the information provided. After systematic review of the relevant literature and discussion of their own experiences, the two hypotheses adopted to test explanations of the cause of any observed socio-technical, policy-related, or institutional change, and the effects of such changes, were:

- that it was the IPs themselves, each considered as an institutional innovation in their own contexts, that caused the observed effects;

- and/or that it was power relationships within and external to the IP that best explained the observed changes.

Within-case analysis proceeded principally on the basis of written background narratives, de-construction of instructive 'critical events', plotting of time paths, inventories of practical strategies adopted for immediate problem-solving, elaboration of alternative explanatory pathways suggested by the two hypotheses and testing these against the evidence, diagramming changes in inter-personal and inter-organisational relationships, analysis of actors' language and of the individual and collective actions and decisions taken by identified actors, and their effects, and reports of the institutional experiments (Jiggins et al., 2016). The experiments covered socio-technical and institutional issues identified by the cocoa IP's members and conducted by a PhD student (Quarmine et al., 2014), and by thematic studies (Adjei-Nsiah et al., 2013; Klerkx et al., 2013; van Paassen et al., 2014; Adu-Acheampong et al., 2014). This paper draws on the totality of this information.

The individuals invited to join a national-level cocoa IP were identified through stakeholder analysis (Nederlof and Pyburn, 2012). They agreed to participate in their personal capacities but they acknowledged from the start that their high-level professional roles and personal networks meant that the new information generated could be passed directly to officials and Cabinet members for political consideration and policy action. The initial membership included Policy Advisor on cocoa affairs to the Minister for Finance and Economic Affairs (on matters concerning) who later became the Director of Research at COCOBOD head office; a senior official of Kuapa Kokoo Ltd (a Licensed Buying Company affiliated to Fair Trade); the head of the Research Department and the Central Regional Manager of the Quality Control Company Ltd; the Managing Director, Cocoa Inputs Company; the Head of Pesticide Residue Laboratory at Ghana Standards Authority; the Bean Warehouse Manager at Cargill Ghana Ltd; the Paramount Chief of Agona Nyakrom Traditional Area. The RA facilitating the work of the IP was based at the Cocoa Research Institute of Ghana (CRIG). A major change to the IP was the joining of the group by a former Director of the national Cocoa $\mathrm{Hi}$-Tech programme that was responsible for input distribution to cocoa farmers.

\section{The institutional context}

\subsection{Policy changes and organizational reforms}

Prior to 2010, policy changes and organizational reforms included:

- successive increases in the percentage of the net f.o.b price paid to farmers;

- liberalization of the internal marketing of cocoa;

- shifting from COCOBOD to the Ministry of Agriculture and then back to COCOBOD the specialised cocoa extension services.

Additional direct interventions by the government included introduction of the Cocoa Disease and Pest Control (CODAPEC) programme in 2001, in response to low adoption levels of recommended pest and disease control measures. This programme was carried out by spraying teams (hired by the government) at set times of the year, throughout the cocoa growing areas. In 2003, the government introduced the cocoa $\mathrm{Hi}$-Tech programme to provide inputs on credit to farmers. The Cocoa Research Institute of Ghana (CRIG) undertook to develop genetically improved clones, together with the International Institute of Tropical Agriculture. 


\subsection{Price regime}

For many years, Ghana has enjoyed a quality price premium for her cocoa exports, and industry leaders at the start of the IP's work were keen to protect this premium against any further declines in bean quality. The government at that time shared part of the export revenues with producers by providing 'free' to cocoa producers various incentives schemes such as educational scholarships for their children, a housing scheme, pension provisions, free spraying of cocoa trees against the most serious cocoa pests, and soil fertility improvement measures. However, farmers indirectly had been paying for these incentives since the costs of the incentive schemes were set off against export revenues, thereby also reducing the margin available to increase the price paid to farmers for their beans. Moreover, in practice the incentives were not available to all cocoa farmers, and the timing of supply of inputs for the mass spraying did not provide adequate control of cocoa pests (Adu-Acheampong et al., 2014). This way of arranging the price regime meant that in 2009 approximately only $70 \%$ of the f.o.b. price was returned to producers.

\section{Findings and analysis}

\subsection{Process narrative: the price regime}

\subsubsection{The main problems}

The IP began by identifying the main problems with the prevailing price regime by sharing for the first time their own experiences, the findings of relevant academic literature, and each of their own organisation's internal data. They noted in particular that:

- not every producer enjoyed the incentive package because of distributional biases;

- the coverage of the annual spraying campaign was widely reported to be uneven, technically inadequate, and economically unsustainable, although data were lacking to support these claims;

- a volatile exchange rate regime meant that often the prevailing rate for setting the f.o.b. price was not equal to the equilibrium level. Thus, the goods that money can buy at the beginning of the cocoa season decreases by the time the cocoa season comes to a close the following year;

- policies that heavily taxed cocoa were destroying farmers' expectation of the long-term profitability of planting and tending cocoa trees.

The IP members emphasised strongly that the continued profitability of the industry depended on smallholders' willingness to invest in producing quality beans but they noted with concern that the mean age of producers was $>50$ years. They further noted the prevalence of aged and moribund plantations, and use of cheap but low performing, non-recommended cocoa planting materials, further limited productivity, and that these problems were clearly linked to the low profit farmers' were receiving. In addition, although various methods for rehabilitating moribund cocoa plantations existed and were known to be effective in increasing yield, farmers were discouraged by inadequate supply by COCOBOD of the improved, recommended planting materials, the cost of establishing new plantations, as well as the associated lag of more than two years before harvestable yields were obtained.

\subsubsection{Producer price formation}

The IP went on to note that the producer price of cocoa in the past had been determined by a cost-price (farm budgeting) approach. By 2010, the government had adopted the f.o.b. sharing method (Quarmine et al., 2014). However, at the start of the IP's inquiry it was unclear what costs were taken into account, or how the information was assembled, and by whom. The IP charged a sub-group of the IP to investigate these points. The sub-group discovered that the following variables were included in the annual price calculations: projected gross f.o.b. in Cedi terms (information available at the Cocoa Marketing Company); the projected Exchange Rate - Cedi/ US dollar (information available at the Bank of Ghana); the projected crop size - output of both main and light crop (information available at COCOBOD Research Department). Other components were a series of cost estimates for: export duty, CODAPEC costs, fertilizer requirements under Hi-Tech, COCOBOD scholarships, Cocoa Roads, farmers' housing and pension schemes, child-labour certification fund and other industry costs. The sub-group noted in addition that bonuses were paid out to farmers only if the actual cocoa sales revenues exceeded the projected estimates.

They argued on the basis of their findings that sustained production of quality cocoa beans would depend on providing farmers with better-targeted incentives, and financial support and transparency in produce marketing. The sub-group also noted that while State agencies ensured that only high quality beans were exported, the question of how to minimise the amount of non-saleable beans, remained unanswered. The quality premium at that time was about $£ 50$ per bag of $64 \mathrm{~kg}$; the sub-group queried whether the share that farmers received was worth the effort that the farmers' needed to make to maintain quality. They began to review alternative ways of formulating price, drawing on 'best practice' lessons from around the world for smallholder and plantation farmers.

These findings were distributed by the IP's Chairman to all members of the IP. They in turn began sharing the information more widely through personal contacts with officials at relevant ministries and the Bank of Ghana. The Policy Advisor on cocoa affairs to the Minister for Finance and Economic Planning, who was also a member of the IP, in September 2010 informed the IP that he had suggested to the Minister of Finance, on the basis of the work of the IP, that CODAPEC operations should be adjusted to allow for an increase in the producer price. Shortly after, the government announced a percentage price increase of $33.3 \%$, (to GH $\notin 200$ per bag of $64 \mathrm{~kg}$ ), a sum considerably higher than the figure proposed by the Producer Price Review Committee (GH $\phi 180$ per bag).

\subsubsection{Inquiry on pricing in neighbouring countries}

The IP member who worked for Cargill, the world's largest cocoa bean trader, was tasked to find out how cocoa pricing was carried out in the Ivory Coast and the Cameroon, because Cargill also operates in those countries. He reported that in the Ivory Coast the market had been partially liberated, with numerous producer organizations claiming to work in the interest of the farmer. These organisations deducted varying but significant amounts from the sale price at the point of delivery by the farmer. The Government announced an indicative price for cocoa beans in advance of the harvest but 
buyers largely ignored the price guidelines, especially in the more remote rural areas, so that different farm level prices operated across the country. As a general rule, the poorer the access roads, the lower the price paid to farmers. He further reported that in the Cameroon the cocoa market was fully liberated: prices paid to farmers were dictated by the London market price prevailing at the time and market forces determined demand and supply. There was no uniform farm gate price. For instance, although the southwest was the highest producing area, the poor state of the roads meant that producer prices were low. In the Central Cameroon, farmer cooperatives sold their beans through an auction system, direct to the market leaders. However, overall Cameroon's farmers tended to be the best paid along the West African coast, and their beans were the most sought after on world markets due to the colour. The IP concluded on the basis of this inquiry that progressive opening of the cocoa industry to the market in Ghana should proceed, under State guidance, but that the State should continue to play a role in governance of the sector to ensure that the enabling environment supported quality production and remained as fair as possible for all cocoa producers.

\subsubsection{Mass spraying campaign as the major cost component}

In a further inquiry process conducted over 2011-2012 the IP documented that cocoa producers across Ghana took few measures to supplement the government's spraying campaign, largely owing to the unavailability of approved pesticides. A study jointly supported by the IP and CRIG (Adu-Acheampong et al., 2014) indicated that the cost of treatment per hectare under CODAPEC was too expensive to be sustained and that the COCOBOD arrangements probably were "making money" for the agro-chemical companies.

The IP also discovered that mass spraying did not reach all farmers. At the inception of the programme in 2001, the government had relied on the stocks held by the Cocoa Input Company that was able to control the distribution of inputs so that no farmers were disadvantaged. Subsequently the government itself organised the distribution system; this had become compromised by costly delays, poor information sharing, poor control over the work of the spraying gangs and patchy coverage. By 2011, the mass spraying campaign formed the highest percentage of the total costs included in the producer price calculations. Moreover, evidence analysed at the request of the IP demonstrated that the mass spraying campaign had become technically ineffective (Adu-Acheampong et al., 2014), not least because the timing, dosage and chemicals used were based on 1970s recommendations.

\subsubsection{Additional findings}

The IP conducted further inquiries for instance into the pricing, distribution and use of fertilisers, and into the rules and actual practices for calculating, registering, and paying out farmers' bonuses, showing both to have become costly, nontransparent and compromised measures. They also drew on the results of a series of institutional experiments (Quarmine et al., 2014). These included a small-scale study of differential pricing, in which farmers were paid higher prices for quality beans. This reduced the quantity of discarded beans, encouraged farmers to invest in quality bean production, and together with other measures encouraged the Licensed Buying Companies (LBCs) to adopt more transparent purchasing procedures. When in 2013 the Cargill IP member warned the IP that the 2012 output of 1 million tonnes of the light crop beans that were preferred by processors threatened to flood world markets, the IP responded by studying the potential to increase domestic consumption. As a result of the study they then encouraged the government to test the promotion of small chocolate bars, offered as a healthy snack through school feeding programmes and LBCs, a proposal that by end 2014 had proved a considerable commercial success.

\subsection{Process narrative: reforming input supply and the mass spraying programme}

Armed with all this new information, the IP in 2013 felt confident enough to suggest to the government that the time had come to reform the entire input supply system for cocoa, and to make suggestions about how this could be done. After careful consideration of the IP's information the government subsequently decided three major reforms of the institutional regime governing input provisions:

- the timing of input distribution, and the quantities of recommended inputs available at district depots would be advertised before the growing season in the newspapers;

- the budget for the mass spraying and Hi-Tech programmes would be reduced (e.g. the free fertilisers supplied to farmers were reduced from 2.2 million bags in 2011-2012 to 500,000 bags in 2012/2013);

- direct government provision of the mass spraying and HiTech programmes would be gradually withdrawn. They recommended that these be replaced by a scheme that guaranteed the continuous supply of and access to cocoa inputs on a commercial basis.

The IP commissioned a special study of the cocoa pest problem and current pest populations affecting cocoa, the efficacy of mass spraying (chemicals used, timing, coverage), and farmers' attitudes regarding alternative ways to provide pest management (Adu-Acheampong et al., 2014). The experts reported their findings to the IP and, through the IP, to the government. The government subsequently decided to terminate over the following years the mass-spraying programme and to move towards an Integrated Pest Management framework for market-based supply by licensed suppliers of up-to-date chemicals effective against the actual pest problem. The government also began to consider how to provide the licensed private suppliers with appropriate pest management information, as well the re-training and support of the cocoa extension workers to that they could provide accurate advice.

\subsection{Causal mechanisms}

As the above process narrative documents, the IP successfully led or catalysed changes that transformed the ways things were done in the cocoa industry. The two mechanisms for these transformations that stand out are shared learning and the progressive amendment of existing institutions. Both were 
identified by the members of the IP as instrumental in bringing about the changes documented. Each is now examined in turn.

\subsubsection{Shared learning}

Shared learning is here exemplified as policy learning among the key players in the cocoa sector who comprised the platform membership, enriched by in-depth, farmer-based field studies and industry-wide inquiries. These inquiries and commissioned studies informed and shaped major policy shifts in the cocoa sector. Content analysis by the authors' of this paper of the process narrative indicates that the following components of the learning process were instrumental to these shifts:

- the IP's decision-making about what and how to learn, and with whom, and about how to share their findings, was controlled by the members, and not by the RA or the COSSIS programme;

- the RA's facilitation of IP meetings encouraged discovery by the IP members of mutual, interdependent interests;

- the platform members themselves identified and analysed their successive research questions: the questions shaping their inquiries and commissioned studies were relevant to their own interests as well as to the interests of the industry as a whole, and concerned topics that (individually or collectively) they and their organisations had a mandate and capacity to act upon;

- the results of the PhD-led institutional experiments, and CRIG-sponsored surveys, were directly communicated to and discussed by the IP;

- the IP did not confine itself only to learning about Ghana's own cocoa industry. The members initiated broad-scale enquiries of matters affecting the global cocoa market. They were able to do so by virtue of the lead position in cocoa trading of one IP member;

- the IP's members had access to, and were prepared to seize, opportunities to convey the new information, as well as their views of what could and should be changed, to the highest levels of the civil service, technical agencies, and to government;

- the platform's composition ensured that it became viewed as the legitimate voice of the cocoa industry as a whole.

\subsubsection{Progressive amendment of existing institutions}

Analysis of the process narrative further shows how the progressive amendment of existing institutions then came about. Two processes stand out:

- the platform members accepted they had a responsibility to act on their collective decisions, arrived at through discussion of the empirical research and enquiry results;

- they had a capacity to act, using the resources of their own organisations as well as their networks of influence and the additional legitimacy gained through their IP membership.

This finding suggests that both the IP as an institutional innovation and pre-existing power relationships were causally important, and that both might be needed if an IP is to transform the 'rules of the game' governing an entire industry.

By 2014, the contribution of the IP had become widely recognised. It was invited to join a new initiative designed to promote better organisation and industry modernisation throughout the west coast cocoa belt. Each cocoa producing country has established a National Platform of Stakeholders coordinated through the African Cocoa Initiative launched in Ghana by the Ministry of Finance and Economic Planning, funded by the World Cocoa Foundation and USAID.

\section{Discussion}

Grindle (2011) suggests that studies such as this are especially valuable in answering policymakers' questions of 'what works and how?'. The narrative and causal mechanisms analysed here reasonably suggest two general lessons, although we acknowledge the difficulty that any co-evolving process embedded in specific circumstance, cannot strictly speaking claim replicability:

- at the level of process, this case highlights the importance of locating responsibility for inquiries, actions and their effects with the IP members themselves;

- in terms of research, the case highlights the importance of joint periodic analysis and review by practitioners and researchers of standard sets of data and information registered in real time, so that IP members can monitor, assess and reflect on their own performance, and its effects and outcomes.

The data and information also provide the material by which to assess the explanatory power of explicit causal hypotheses. Both elements could be said in turn to strengthen the learning potential and capacity of IPs.

Finding out about 'what works for cocoa smallholders?' is a perennial challenge for policy makers and sector leaders farremoved from the lives of farmers on whose efforts the success of the sector relies. Smallholders, on the other hand, typically have little understanding of what their efforts contribute to the entire value chain or the interests of other stakeholders. More than twenty years' ago Chambers (1994) analysed the numerous, persistent 'errors, which fly in the face of facts which seem to have been known and knowable', and on which policy-makers and service providers alike continue to operate. An IP provides a new kind of social space in which these errors can be confronted and new, more reliable knowledge brought to bear. Unusually, however, in this case the IP members focussed on learning in addition about institutional rather than purely socio- technical hindrances and opportunities for change, as well as investing time and effort into the effects and outcomes of their actions and recommendations. Van Paassen et al. (2014), analysing the cocoa IP and other IPs supported by COS-SIS identify these activities as core skills in the development of capacity for 'strategic institutional entrepreneurship' i.e. creative capacity and collective purpose to transform what is done and how things are done.

The IP set out to examine, and where necessary transform official and informal rules, including policy frameworks (legitimising action and decisions); practices and incentives (constituting the material structures for action); the scope and quality of relationships; and the rules for interpreting meaning and knowledge development (creating fresh understanding of what is significant and who and what is involved in sensemaking). Purposeful shared learning, accomplished under the IP's direction, is identified in this paper as one of the key mechanisms for driving change in these institutional elements. 
Taking responsibility for various kinds of informed action to bring about purposeful change is another, identified as particularly effective when coupled to feedback on the effects and outcomes of the actions taken. Faure et al. (2010) similarly emphasise 'pas de recettes, mais une démarche' (no recipes but an approach). This emphasis on learning together, and on discussing and communicating to others information about what has been learned, is very different to the idea that 'knowledge' is something that can be transferred, although this idea is commonly expressed in everyday speech. Strictly speaking, knowledge is constituted by a person's unique life experiences; thus an experience can be enjoyed in common with others but never becomes a 'common experience'. What can be 'transferred' is information about an experience (including the experience of a scientific experiment and its outcomes) and the cocoa IP members developed considerable skill in strategic communication of their experiences.

\section{Conclusion}

This case indicates how an appropriately constituted and positioned IP can help transform the governance, institutions and technical components of an entire industry. The motivation of the IP members to act, and the willingness of the government to listen to and act on the IP's suggestions, was compelled by deteriorating conditions within the industry and the need to maintain market share and bean quality.

Acknowledgements. The authors gratefully acknowledge the contributions of their partners in the COS-SIS programme, supported by the Netherlands Ministry of Foreign Affairs, the members of the cocoa IP, and their many colleagues in Ghana, Benin and Mali who guided them on their journey. This paper is published with the kind permission of the Executive Director of the Cocoa Research Institute of Ghana.

\section{References}

Adjei-Nsiah S, Adu-Acheampong R, Debrah K, Dembélé F, Lassine S, Ouologuem B, et al. 2013. Defying "the pervasive bias" against African smallholders: identifying entry points for institutional change. Development in Practice 23(7): 857-871. Available from http://www. tandfonline.com/doi/full/10.1080/09614524.2013.811220.

Adu-Acheampong R, Jiggins J, van Huis A, Cudjoe AR, Johnson V, Sakyi-Dawson O, et al. 2014. The cocoa mired (Hemiptera: Miridae) problem: evidence to support new recommendations on the timing of insecticide applications on cocoa in Ghana. International Journal of Tropical Insect Science 34(1): 58-71.
Avelino F, Rotmans J. 2009. Power in transition. An interdisciplinary framework to study power in relation to structural change. European Journal of Social Theory 12(4): 543-569.

Baah F, Garforth C. 2008. Insights into cocoa farmers' attitudes in two districts of Ashanti, Ghana. International Journal of Sustainable Development 1: 8-14.

Chambers R. 1994. Knowledge and power. IDS Bulletin 25(2): $14-26$.

Faletti TG, Lynch JF. 2009. Context and causal mechanisms in political analysis. Comparative Political Studies 42: 1143-1166.

Faure G, Gasselin P, Triomphe B, Temple L, Hocdé H, eds. 2010. Innover avec les acteurs du monde rural : la recherche-action en partenariat. Versailles : Éditions Quae, CTA, Presses agronomiques de Gembloux.

Fuchs D, Graab F. 2011. Material power and normative conflict in global and local agrifood governance. The lessons of 'Golden Rice' in India. Food Policy 36: 729-735.

Grindle M. 2011. Governance reform: the new analytics of next steps. Governance: An Internaitonal Journal of Policy Administration and Institutions 24(3): 415-418.

Hounkonnou D, Brouwers J, van Huis A, Jiggins J, Kossou D, Röling $\mathrm{N}$, et al. 2016. Triggering regime change: a comparative analysis of the performance of innovation platforms that attempted to change the institutional context for nine agricultural domains in West Africa. Agricultural Systems. Available from https://doi.org/ 10.1016/j.agsy.2016.08.009.

Jiggins J, Hounkonnou D, Sakyi-Dawson O, Kossou D, Traoré M, Röling N, et al. 2016. Introduction: innovation platforms to support smallholder development - Experiences from Sub-Saharan Africa. Cahiers Agricultures 25(6): 64002. DOI:10.1051/cagri/2016051.

Klerkx L, Adjei-Nsiah S, Adu-Acheampong R, Saïdu A, Zannoue E, Soumano L, et al. 2013. Innovation platforms through an innovation platform lens. An analysis of three cases in West Africa. Outlook on Agriculture 42(3): 185-192.

Nederlof S, Pyburn R, eds. 2012. One finger cannot lift a rock. Facilitating innovation platforms to trigger institutional change in West Africa. Amsterdam: Royal Tropical Institute.

Quarmine W, Haagsma R, van Huis A, Sakyi-Dawson O, Obeng-Ofori D, Asante F. 2014. Did the price-related reforms in Ghana's cocoa sector favour farmers? International Journal of Agricultural Sustainability 12(3): 248-262.

Sterk B, Kobina AC, Gogan AC, Sakyi-Dawson O, Kossou D. 2013. Five years after: the impact of a participatory technology development programme as perceived by smallholders in Benin and Ghana. International Journal of Agricultural Education and Extension 19(4): 361-379.

van Paassen A, Klerkx L, Adu-Acheampong R, Adjei-Nsiah S, Zanoue E. 2014. Agricultural innovation platforms in West Africa: how does strategic institutional entrepreneurship unfold in different value chain contexts? Outlook on Agriculture 43(3): 193-200.

Cite this article as: Adu-Acheampong R, Jiggins J, Quartey ET, Karikari NM, Jonfia-Essien W, Quarshie E, Osei-Fosu P, Amuzu M, Afari-Mintah C, Ofori-Frimpong K, Owusu-Manu M, Eku X NN, Sakyi-Dawson O, Quarmine W, Acquah FO. 2017. An innovation platform for institutional change in Ghana's cocoa sector. Cah. Agric. 26: 35002. 